\title{
Relationship between the Temperature Given at the Time of Fertilized Egg Formation and Bisexual Reproduction Pattern in the Deriving Strain of the Rotifer Brachionus plicatilis ${ }^{* 1}$
}

\author{
Akinori HINO*2 and Reijiro HiRANo*2 \\ (Accepted August 17, 1984)
}

\begin{abstract}
Temperature given at the time of fertilized (resting) egg formation in the rotifer Brachionus plicatilis was discussed, from a point of view that it may cause great difference in bisexual reproductivity among the deriving strains.

Fertilized eggs were produced at five temperatures $\left(17,20,25,27\right.$ and $\left.30^{\circ} \mathrm{C}\right)$ in sea water. Neonates from the eggs were employed as stem mothers of respective experimental strains. Every strain consisted of isogenic individuals through keeping parthenogenesis, which was ensured by the individual culture in $0.1 \mathrm{~m} l$ sea-water medium. Media were renewed at regular intervals of 12,24 or 36 hours at 30,25 or $20^{\circ} \mathrm{C}$ respectively in order to prevent the accumulation of metabolites which is an exciting cause of bisexual reproduction.

The temperature given in the process of fertilized egg formation determines the bisexual reproduction pattern of deriving strains. Among the strains derived from the fertilized eggs which were produced at high temperature over $25^{\circ} \mathrm{C}$, the appearance rate of mictic females has no relation to temperature. Among those, however, derived from the eggs originating in low temperature below $25^{\circ} \mathrm{C}$, it varies inversely with temperature below $25^{\circ} \mathrm{C}$, but not affected above $25^{\circ} \mathrm{C}$.
\end{abstract}

Bisexual reproduction in the rotifer Brachionus plicatilis is clearly induced under high population density ${ }^{1-3)}$ or a low temperature." The authors observed in the further inquiries that the change of mictic female production rate with temperature differs among strains, although they commonly produce mictic females at a low temperature. In this study, the origin of the phenomenon was investigated, taking notice of the temperature conditioned at the time of fertilized egg (resting egg) formation. Fertilized eggs were produced at five temperatures and stored, and then mictic female production rates of the new strains originated from those fertilized eggs were compared at three temperatures.

The similar phenomena that the history of resting eggs affects the mode of reproduction among deriving descendants are well known in insects, and also studied by Stross and $\mathrm{HILl}^{\mathrm{s} \text { ) }}$ in the Cradocean Daphnia which has similar life cycle to rotifers. D. pulex bore more male offsprings in the swarm originating from those resting eggs which had been produced under short-day periodicity.

\section{Materials and Methods}

B. plicatilis was the same stock as examined in previous reports ${ }^{3,4)}$ and cultured in sea water of which chlorinity was adjusted at $16 \%$. All rotifer cultures were kept in the dark.

\section{Massculture for Fertilized Egg Formation}

Massculture for collecting fertilized eggs was carried out in $500-2000 \mathrm{~m} /$ of culturing media as shown in the left half of Fig. 1. Chlamydomonas $\mathrm{sp}$. of marine species was supplied once a day for food so as to be $3 \times 10^{3} \mathrm{cells} / \mathrm{m} l$ after centrifuged. Yeast could not be utilized, because few fertilized eggs were produced by the strains examined when it was provided with. Rotifer density was adjusted at 100 individuals $/ \mathrm{m} l$ also once a day through eliminating excess rotifers with a plankton net cloth.

Temperature condition was graded into five: $\mathrm{A}$; $17^{\circ} \mathrm{C}, \mathrm{B} ; 20^{\circ} \mathrm{C}, \mathrm{C} ; 25^{\circ} \mathrm{C}, \mathrm{D} ; 27^{\circ} \mathrm{C}$ and $\mathrm{E} ; 30^{\circ} \mathrm{C}$.

\section{Successive Culture for Testing Bisexual Repro- ductivity \\ From each egg lot, 7 to 20 neonates, that is the}

* A part of this study was supported by a Grant-in-Aid for Scientific Research.

*2 Department of Fisheries, Faculty of Agriculture, The University of Tokyo, Yayoi 1-1, Bunkyo, Tokyo 113, Japan (日野明徳・平盽礼次郎：東京大学宸学部水産学科). 


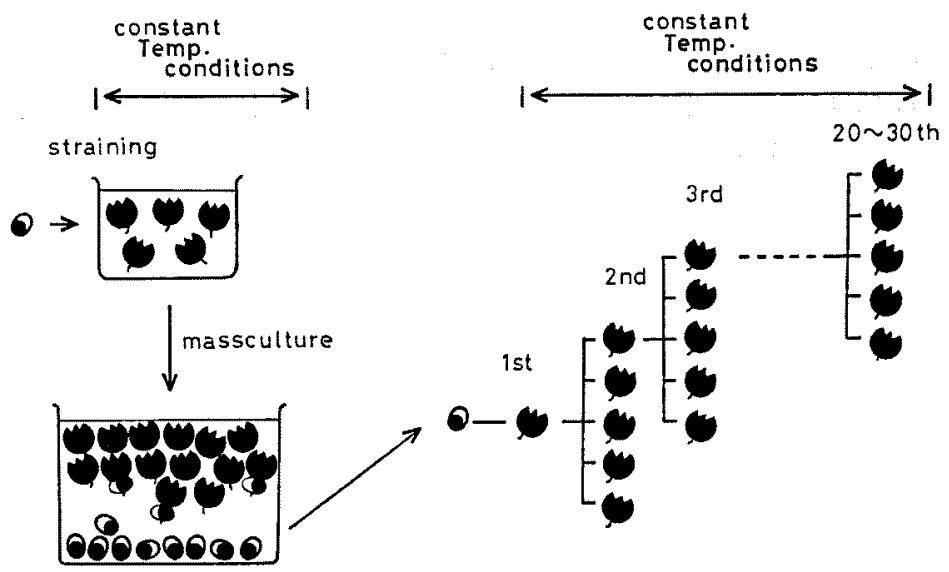

Fig. 1. Procedures in testing the effect of temperatures which were given in the process of fertilized egg formation.

left half: process of fertilized egg formation under five temperature conditions.

right half: successive culture in testing the bisexual reproductivity under three temperature conditions.

first generation were hatched out through incubating at $25^{\circ} \mathrm{C}$ for two days under continuous illumination $(2000 \mathrm{~lx})$. Straining was made by employing the first generation as the stem mother of a strain. After that, neonates were produced successively by parthenogenesis. Accordingly, any individual in the same strain has the identical gene. In every generation of a strain, the first daughter was employed as the mother of next generation (right half of Fig. 1).

Culturing medium was food suspended sea water of which chlorinity was $16 \%$. Dry yeast for baking was provided as food without any activation for testing bisexual reproductivity at different temperatures, intending to avoid the possible interference caused by physiological conversion of live green algae. The food density was adjusted at $10^{7}$ cells $/ \mathrm{m} l$.

Any rotifer was cultured individually in a glass tube containing $0.1 \mathrm{ml}$ culture medium, and transferred into new medium at regular intervals (T). If a newly hatched neonate was observed then, it was transferred into another culture tube. The time interval " $T$ " was determined in proportion to the metabolic level varied with each temperature in order to nullify the density effect on mictic female production as shown in the previous report, ${ }^{4)}$ which was 12,24 and $36 \mathrm{~h}$ at 30,25 and $20^{\circ} \mathrm{C}$ respectively.

In the course of successive culture, substraining was made twice in order to be assigned for the



Fig. 2. Effect of the temperature given in the process of fertilized egg formation on the variation of bisexual reproduction pattern in deriving new strains.

egg origin: the temperature at which fertilized eggs as ancestry of experimental strains were formed. 
Table 1. History of fertilized egg formation and the frequency of bisexual reproduction in the deriving strain

\begin{tabular}{|c|c|c|c|c|c|c|}
\hline \multirow{2}{*}{ Egg origin* } & \multicolumn{3}{|c|}{ Temp. experimented } & \multicolumn{3}{|c|}{ Temp. experimented } \\
\hline & $20^{\circ} \mathrm{C}$ & $25^{\circ} \mathrm{C}$ & $30^{\circ} \mathrm{C}$ & $20^{\circ} \mathrm{C}$ & $25^{\circ} \mathrm{C}$ & $30^{\circ} \mathrm{C}$ \\
\hline \multicolumn{7}{|l|}{ series } \\
\hline A: $17^{\circ} \mathrm{C}$ & $\begin{array}{l}52 / 136 \\
(38.2 \%)\end{array}$ & 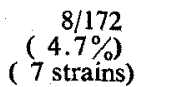 & $\begin{array}{l}3 / 315 \\
(1.0 \%)\end{array}$ & & & \\
\hline $\mathrm{B}: 20^{\circ} \mathrm{C}$ & $\begin{array}{l}56 / 366 \\
(15.3)\end{array}$ & $\begin{array}{c}71 / 752 \\
(9.4) \\
\text { (13 strains) }\end{array}$ & $\begin{array}{c}28 / 325 \\
(8.6)\end{array}$ & $\begin{array}{c}58 / 392 \\
(14.8)\end{array}$ & $\begin{array}{c}56 / 638 \\
(8.8) \\
\text { (14 strains) }\end{array}$ & $\begin{array}{r}46 / 446 \\
(10.3)\end{array}$ \\
\hline $\mathrm{C}: 25^{\circ} \mathrm{C}$ & $\begin{array}{c}123 / 512 \\
(24.0)\end{array}$ & 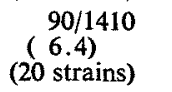 & $\begin{array}{c}57 / 868 \\
(6.6)\end{array}$ & $\begin{array}{r}31 / 272 \\
(1.4)\end{array}$ & $\begin{array}{c}56 / 576 \\
(9.7) \\
\text { (14 strains) }\end{array}$ & $\begin{array}{c}18 / 285 \\
(6.3)\end{array}$ \\
\hline $\mathrm{D}: 27^{\circ} \mathrm{C}$ & $\begin{array}{l}53 / 447 \\
(11.9)\end{array}$ & $\begin{array}{c}117 / 1092 \\
\text { (10.7) } \\
\text { (16 strains) }\end{array}$ & $\begin{array}{l}59 / 463 \\
(12.7)\end{array}$ & & & \\
\hline $\mathrm{E}: 30^{\circ} \mathrm{C}$ & $\begin{array}{l}33 / 335 \\
(9.9)\end{array}$ & $\begin{array}{l}79 / 1059 \\
(7.5) \\
(17 \text { strains })\end{array}$ & $\begin{array}{l}60 / 457 \\
(13.1)\end{array}$ & $\begin{array}{r}46 / 352 \\
(13.1)\end{array}$ & $\begin{array}{c}52 / 582 \\
(8.9) \\
\text { (12 strains) }\end{array}$ & $\begin{array}{r}16 / 197 \\
(8.1)\end{array}$ \\
\hline
\end{tabular}

- temperature given at the time of fertilized egg formation.

experimentations at 20 and $30^{\circ} \mathrm{C}$ respectively. The next available daughter other than the first was employed as the stem mother of a substrain then. Consequently, the identical strains could be alloted to all three temperature conditions.

In each temperature condition, bisexual reproduction rate, namely the rate of mictic females was calculated after summing up both numbers of amictic and mictic females which had appeared among the eldest five daughters of each generation.

\section{Results and Discussion}

The data before the seventh generation after hatching of fertilized eggs were omitted, in the light of past informations ${ }^{4,8}$ that the ability of bisexual reproduction responding to some external factor could not be acquired till near then. Also, the data from the two generations since transferred into different temperature were omitted, in order to avoid the effect of temperature alteration.")

Table 1 shows the ratio of mictic females appearing among 13086 females which could be distinguished whether amictic or mictic under three temperature conditions. The number of those strains which could be examined under all three temperatures in common was 113.

In each identical strain, the percentages of mictic females were compared among those three temperatures, and the remainders of percentages were found between adjoining two conditions. These remainders were arranged according to tested strains and analyzed by Wilcoxon's signed rank test or paired sample t-test, which enabled to disregard the hereditary differences in bisexual reproductivity existing among strains. In Fig. 2, solid line indicates the significant difference above $95 \%$ confidence level.

Commonly to any experiment, there is no significant difference in the percentage of mictic female production between 30 and $25^{\circ} \mathrm{C}$. In contrast, the results of mictic female production in 25 and $20^{\circ} \mathrm{C}$ depend on egg origin. When the rotifer strains are derived from the fertilized eggs which had been produced at low temperatures ( 20 and $17^{\circ} \mathrm{C}$ in this study), more mictic females are produced in the rearing at $20^{\circ} \mathrm{C}$. In the case of those eggs which were produced at high temperatures ( 30 and $27^{\circ} \mathrm{C}$ in this study), there is no significant difference between 20 and $25^{\circ} \mathrm{C}$ in the rearing of deriving strains. The strains deriving from the eggs which have been produced at $25^{\circ} \mathrm{C}$ show an eclectic tendency; $25^{\circ} \mathrm{C}$ is thought to be critical temperature.

In a different expression, it is summarized as follows. The temperature given in the process of fertilized egg formation determines the bisexual reproduction pattern of hatched strains. Among the strains derived from the fertilized eggs which had been produced under a high temperature (over $25^{\circ} \mathrm{C}$ in this study), the appearance rate of mictic females would not be affected by culturing temperature. Among those, however, derived from the eggs originating in a low temperature (under $25^{\circ} \mathrm{C}$ in here), it varies inversely as temperatures 
below $25^{\circ} \mathrm{C}$, but not affected above $25^{\circ} \mathrm{C}$.

It is suggested that the environmental conditions which had been given in the course of fertilized egg formation can be the origin of the internal factor that there lies great difference in bisexual reproductivity among the deriving strains. This may assure the breeding of $B$. plicatilis for massculture and resting egg formation, because bisexual reproduction is interruptive for massculture but essential for resting egg formation as well.

\section{References}

1) A. Hino and R. Hirano: Kagaku to Seibutsu, 13, 516-521 (1975).

2) M. Pozuelo: Publ. Te'c: Junta Est, Pesca, 11, $401-416$ (1975).

3) A. Hino and R. Hirano: Bull. Japan. Soc. Sci. Fish., 42, 1093-1099 (1976).

4) A. Hino and R. Hirano: Bull. Japan. Soc. Sci. Fish., 50, 1481-1485 (1984).

5) R. G. Stross and J. C. Hill: Biol. Bull., 134, 176-198 (1968)

6) A. Hino and R. Hirano: Bull. Japan. Soc. Sci. Fish., 43, 1147-1155 (1977). 